US experts draw up guidelines for stem-cell research

Erika Check, Washington

US stem-cell research needs a coherent set of rules, according to experts from the National Academy of Sciences.

Every institution working with human embryonic stem cells should create a committee to oversee the research, says the panel, which also recommends that some experiments should be banned.

"We think it's very important that everyone who's doing this work is operating in the same spirit, and with the same conditions of transparency and care," says bioethicist Jonathan Moreno of the University of Virginia in Charlottesville, who co-chaired the panel. At present, much research on human embryonic stem cells in the United States is funded from private sources, placing it largely beyond the reach of federal regulations.

In its 26 April report, the panel says that committees should conduct different levels of review for various stem-cell experiments, according to the ethical challenges they pose. "We decided to set up categories to give guidance as to how to think about these things," says panel co-chair Richard Hynes, a cell biologist at the Massachusetts Institute of Technology in Cambridge.

For instance, to study cell development, some scientists want to inject human embryonic stem cells into other species' blastocysts - embryos just a few days old that consist of a hollow ball of cells (see Nature 431, 885; 2004). The panel argues that such proposals would require thorough review and that experiments with blastocysts from primates should be banned because of the danger that the 'chimaera' produced could develop to term. "Some things should not be done because they cross ethical lines," says Hynes.

The panel wants at a local level what some other countries have on a national basis. Australia, Britain and Canada have set up national committees to regulate stem-cell research. And in 2002, Singapore's Bioethics Advisory Committee recommended that its government do the same.

In the absence of federal guidelines, it seems the panel's recommendations provide a reasonable blueprint. "I hope they can help us move forward and establish the field," says Leonard Zon of the Children's Hospital Boston, current president of the International Society for Stem Cell Research.
IMAGE

UNAVAILABLE FOR COPYRIGHT REASONS

Safety in numbers: children who go to day care early in life are less likely to develop leukaemia.

\title{
Link to infection raises hope of preventing child leukaemia
}

Roxanne Khamsi, London

It is finally possible to identify the environmental factors responsible for childhood leukaemia, researchers told a meeting in London last week. Now it's time to think about how to prevent the disease, they said.

Exposure to radiation, chemicals and power lines are not a significant cause, the meeting heard. In fact, most cases are caused by common infections in toddlers.

Leukaemia causes the production of abnormal white blood cells, and accounts for a third of cancers in children. Some genetic predisposition is involved, but for decades scientists have been trying to identify what triggers the disease.

The biggest effort is the United Kingdom Childhood Cancer Study, set up in 1991. It compiled information from more than 10,000 children, including some 1,700 with leukaemia.

Researchers from the project met last week to discuss the results. They were agreed on the role of chemicals and radiation. "Perceived risk factors such as living near sources of electromagnetic fields or natural radiation are not principal causes, if at all, of leukaemia in children," says Mel Greaves of the Institute of Cancer Research in London.

Infections, on the other hand, induce a proliferation of white blood cells in bone marrow as part of the normal immune response. In children genetically predisposed to leukaemia, the researchers think that infection might cause an uncontrolled proliferation of cells, leading to cancer.

Although several studies have hinted that infection could be a cause, it has taken the size and statistical power of the UK pro- ject to convince researchers that there really is a significant link. To do this, epidemiologist Eve Roman of the University of York and her team analysed data on children's day-care attendance.

Records from East Germany had hinted that infants sent to playgroups from the age of three months were less likely to contract leukaemia. So Roman's team set out to test whether exposure to infections very early in life could somehow train the immune system to protect against the cancer.

They focused on acute lymphoblastic leukaemia, a common form of the disease that usually strikes between the ages of two and five - the time most children start going to playgroups. The team found that children who attended day care during the first three months of life had half the normal risk of developing the disease (C. Gilham et al. Br. Med. J. doi:10.1136/bmj. 38428.521042.8F; 2005).

Attention is now turning to how to prevent leukaemia. Encouraging parents to send their children to playgroups early in life is one obvious option. Identifying the infections responsible also raises the possibility of developing protective vaccines. Greaves notes that US and Finnish studies have suggested that the Hib vaccine against meningitis also helps to protect against leukaemia.

Charles Stiller, a cancer epidemiologist at the University of Oxford, UK, is excited about the shift but cautions against getting too carried away. "It's difficult to know what proportion of cases is accounted for by infections," he says. "And there is more to be done on defining the mechanisms by which this might work." 